学術論文

\title{
漏洩磁束測定による金属材料の弾塑性変形評価
}

\section{Evaluation of Elastic-Plastic Deformation of Metal by Magnetic Flux Leakage Measurement}

\author{
安部 正高 ${ }^{* 1}$ (正員), 松本 英治 ${ }^{* 1}$ (正員)
}

\author{
Masataka ABE (Mem.), Eiji MATSUMOTO (Mem.)
}

\begin{abstract}
This study intends to assess elastic and plastic deformation of carbon steel (SS400) and austenitic stainless steel (SUS304) by measuring magnetic flux leakage near a specimen surface using a hall sensor with high sensitivity and high spatial resolution. We measure the tangential components of Magnetic Flux Leakage near the specimen surface under residual magnetization condition. In the results, it is confirmed the MFL signal shows characteristic trend with respect to the elastic and plastic deformation. Furthermore, it is shown that the distribution of plastic deformation and residual stress can be estimated by MFL distribution.
\end{abstract}

Keywords: magnetic flux leakage, elastic deformation, plastic deformation, SS400, SUS304, NDE.

\section{1 緒言}

強磁性体の磁化的特性と力学的特性との相互作用 は磁気弾性結合効果と呼ばれ, 磁歪や応力磁化効果な どが知られている[1]。この磁気弾性結合効果は磁性体 中の磁区構造が磁気エネルギーや磁気弾性エネルギー を小さくするように変化することに起因する。この効 果によって, 応力負荷で弾性変形した磁性材料の磁化 特性が変化することを利用し, 磁気的な測定によって 応力評価を行う手法が多く研究・開発されている[2-4]。 また，強磁性体の磁化特性は塑性変形にも強く依存す ることが知られている。これは, 塑性変形によって増 殖した転位による磁壁のピン止め効果の増加や, 転位 周辺での磁気モーメントの乱れに起因する。この性質 を利用して塑性変形や疲労損傷などを磁気的に評価す る手法についても盛んに研究されている[5]。

一方で, 各種機械構造物の構造材料として炭素鋼と ともに広く用いられているステンレス鋼のうち, SUS304 鋼や SUS316 鋼などのオーステナイト系ステ ンレス鋼は一般に非磁性とされているが，応力負荷や 塑性変形, 疲労によって磁性を持つマルテンサイト相 が生成することが知られている。このことを利用して, 磁気的にオーステナイト系ステンレス鋼材の探傷, な らびに塑性変形や疲労の評価を行う手法の研究が進め られている[6,7]。

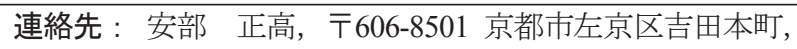
京都大学大学院エネルギー科学研究科

e-mail: abe@energy.kyoto-u.ac.jp

${ }^{* 1}$ 京都大学大学院エネルギー科学研究科
一般に，磁気的評価手法においては，材料の磁気特 性を直接測定することが望ましいが，測定対象からの サンプリングや加工が必要であり，現場での非破壊的 な評価を行う際には問題となる。また, 塑性変形の局 所的な分布などを評価することは難しい。他方で，弾 塑性変形やマルテンサイト相の生成によって材料中の 磁気特性が不連続となる場合, その周辺では磁束の変 化が生じると考えられる。そこで本研究では，塑性変 形や残留応力にともなう材料中の磁気特性の非均一な 分布を材料表面近傍の空間磁場（漏洩磁束）として間 接的に測定することで，塑性変形や応力の分布を評価 することを試みた。材料としては低炭素鋼の SS400 鋼 とオーステナイト系ステンレス鋼の SUS304 鋼を対象 とした。まず, 弾性域の引張応力に対する漏洩磁束密 度の変化を測定し，その傾向を調べた。続いて，塑性 域まで引張応力を負荷・除荷し, 残留ひずみを有する 試験片について同様に漏洩磁束密度を測定し, 残留ひ ずみとの相関を調べた。この際，大規模地震などによ り大変形を生じた構造部材の評価への応用も念頭に入 れて, 5\%程度までの残留ひずみについての相関を調心゙ た。最後に，局所的に応力集中を生じる試験片につい て塑性域の引張応力を負荷・除荷し, 残留ひず夕分布 を有する試験片について漏洩磁束密度を測定し，その 分布から残留ひずみおよび残留応力分布を推定した。

\section{2 実験方法}

\section{1 試験片}

今回の実験には SS400 鋼および SUS304 鋼を使用し 
た。Table 1 に使用した SS400 鋼と SUS304 鋼について 引張試験を行って得た機械特性の一部を示す。まず, 弾性域の引張忘力を負荷した状態で漏洩磁束測定を行 うための弾性域測定用試験片として, Fig. 1 の形状の 試験片を SS400 鋼 (E 試験片) については 3 本, SUS304 鋼（SE 試験片）については 1 本作成した。また, 塑性 域までの引張応力を負荷・除荷し, 残留ひずみを有す る塑性域測定用試験片として, Fig. 2 に示す試験片を $\mathrm{SS} 400$ 鋼（P 試験片）と SUS304 鋼（SP 試験片）につ いて作成した。塑性域測定用試験片は，塑性変形が確 実に試験片中央部で発生し，かつある程度一様に変形 するように緩やかな R をつけた形状とした。塑性域測 定用試験片は Table 2 に示すように，SS400 鋼（P 試験 片)においては各試験片において最大ひずタが $1.25 \%$, 2.50\%，3.75\%，5.00\%となるように，SUS304 鋼（SP 試験片）においては各試験片において最大ひずみが

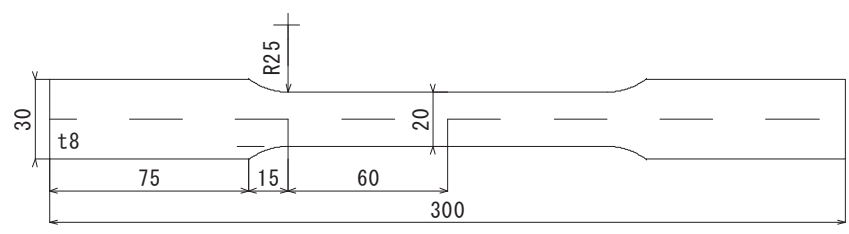

Fig. 1 Specimen for elastic region measurement.

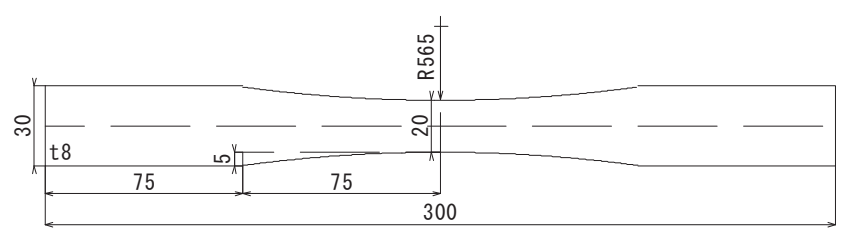

Fig. 2 Specimen for plastic region measurement.

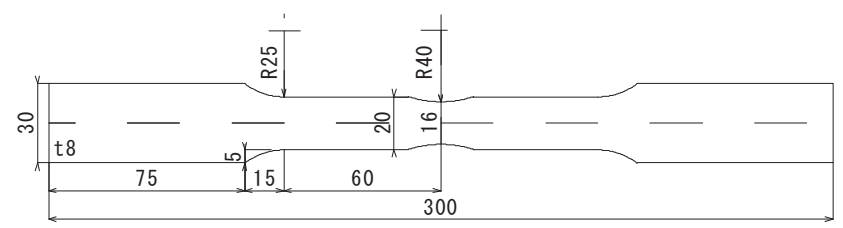

Fig. 3 SS400 stress concentration type specimen.

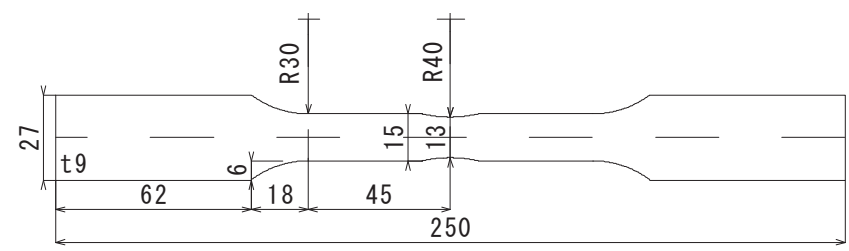

Fig. 4 SUS304 stress concentration tvpe specimen.
$1.00 \% ， 2.00 \% ， 3.00 \% ， 4.00 \%$ となるように引張荷重を 与えた後に除荷し, 異なる残留ひずみを生じさせた試 験片をそれぞれ複数本用意した。最後に，弾性域およ び塑性域測定用試験片により得た基礎データをもとに， 実際に残留ひずみや残留応力の分布を評価するための 試験片として, Fig. 3 および Fig. 4 に示す応力集中型試 験片を作成した。Fig. 3 は SS400 鋼（D 試験片)，Fig. 4 は SUS304 鋼（SD 試験片）の試験片形状である。Table 3 に示すように D 試験片は，応力集中部における最大 ひずみが 3.00\%および 5.00\%になるように引張荷重を 与えた後に除荷したものと，形状の影響の有無を検証 するために引張荷重を加えない試験片も 1 つ用意した。 一方， SD 型試験片は，応力集中部における最大ひず みが 3.00\%となるように引張荷重を与えた後に除荷し たもののタ用意した。

Table 1 Mechanical properties of SS400 and SUS304.

\begin{tabular}{c|c|c} 
& SS400 & SUS304 \\
\hline \hline Yield stress & $327 \mathrm{MPa}$ & $660 \mathrm{MPa}$ \\
$/ 0.2 \%$ proof stress & & \\
\hline Young's modules & $209 \mathrm{GPa}$ & $191 \mathrm{GPa}$
\end{tabular}

Table 2 Maximum and residual strain of specimen for plastic region measurement.

\begin{tabular}{c|c|c} 
Specimen No & Max. strain & Residual strain \\
\hline P-1 & 0.0125 & 0.0111 \\
\hline P-2 & 0.0250 & 0.0232 \\
\hline P-3 & 0.0375 & 0.0353 \\
\hline P-4 & 0.0500 & 0.0476 \\
\hline P-5 & 0.0125 & 0.0109 \\
\hline P-6 & 0.0250 & 0.0232 \\
\hline P-7 & 0.0375 & 0.0353 \\
\hline P-8 & 0.0500 & 0.0476 \\
\hline P-9 & 0.0125 & 0.0109 \\
\hline P-10 & 0.0250 & 0.0231 \\
\hline P-11 & 0.0375 & 0.0358 \\
\hline P-12 & 0.0500 & 0.0476 \\
\hline SP-1 & 0.0100 & 0.0059 \\
\hline SP-2 & 0.0200 & 0.0155 \\
\hline SP-3 & 0.0300 & 0.0252 \\
\hline SP-4 & 0.0400 & 0.0351
\end{tabular}

Table 3 Maximum and residual strain of stress concentration type specimen.

\begin{tabular}{c|c|c} 
Specimen No. & Max. strain & Residual strain \\
\hline \hline D-1 & 0 & 0 \\
\hline D-2 & 0.0300 & 0.0284 \\
\hline D-3 & 0.0500 & 0.0477
\end{tabular}




\section{2 測定方法}

測定機器の概略図を Fig. 5 に示寸。試験片は島津製 作所製万能試験機（オートグラフ AG-50KE）に固定さ れており，COMS 製 3 軸ステージ（RAP-3）に固定さ れた磁気センサプローブを走査することで試験片表面 近傍の磁束密度を測定する。磁気センサプローブの反 対面側には消磁および着磁の際に住友通商社製電磁石 （特注品，2000 巻）を設置する。試験片は測定毎に消 磁および着磁を行う。試験片の磁化は直流磁化とし, 残留磁化状態での漏洩磁束の測定を行った。磁化方向 は試験片長手方向で, 磁化電流值は 3(A)である。磁気 センサには電子磁気工業社製ホールセンサ（T-550）を 用い，同社製ガウスメータ（GM-5005）とアジレント 社製デジタルマルチメータ（34970A）を通してパソコ ンに值を取り込む。本センサのエレメント部は $50 \mu \mathrm{m}$ 角と空間分解能が高く, $\pm 4(\mathrm{~T})$ の広い測定レンジと $10^{-7}(\mathrm{~T})$ の高感度を併せ持っている。測定する磁束密度 成分は試験片表面に対して接線方向成分（長手方向） とした。測定範囲は，弾性域および塑性域測定用試験 片については，試験片の片面中央部 $10 \mathrm{~mm} \times 10 \mathrm{~mm} の$ 領域を, 応力集中型試験片の測定においては，片面中 央部 $10 \mathrm{~mm} \times 60 \mathrm{~mm}$ の領域を測定した。すべての測定 において, 測定間隔は $1 \mathrm{~mm}$, リフトオフは $0.5 \mathrm{~mm}$ で 統一した。弾性域の引張応力を負荷した状態での測定 において, SS400 鋼では公称応力 $0 \mathrm{MPa}$ から $200 \mathrm{MPa}$ まで $20 \mathrm{MPa}$ 毎の各応力を引張試験機で負荷しながら 測定を行った。また, SUS304 鋼では 0MPaから 250MPa まで $25 \mathrm{MPa}$ 毎の各応力を引張試験機で負荷しながら 測定を行った。

\section{3 実験結果と考察}

\section{1 弾性域}

Fig.6 と Fig.7 に SS400 鋼と SUS304 鋼の弾性域の各 引張応力下において測定された漏洩磁束密度分布の一

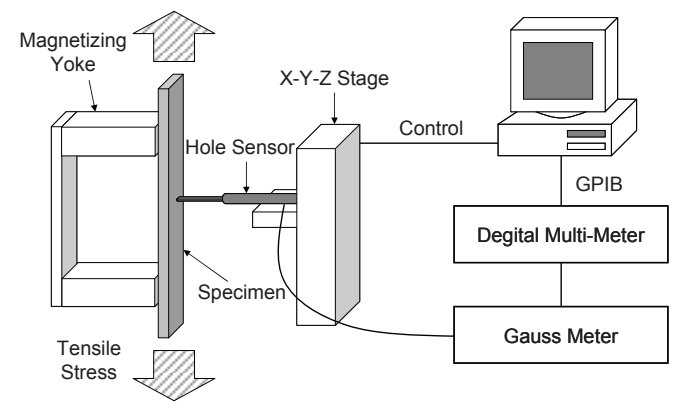

Fig. 5 Experimental system.
例を示す。また, Fig. 8 と Fig. 9 には各材料の測定領域 内の平均值を応力に対してプロットしたものを示す。

Fig. 8，Fig. 9 において(a)には測定前に行った消磁操作 後の測定值を，(b)には測定值そのものを，(c)には(a) の消磁操作後の測定值を差し引いた值（消磁基準補正 值）の結果を示した。これは, 環境磁場やセンサのド リフトの影響を取り除くためのひとつの方法である。

Fig. 8 に示寸ように, SS400 鋼においては引張応力の増 加とともに漏洩磁束は一度減少してから再び増加寸る 傾向があることがわかった。我々の研究室では SS400

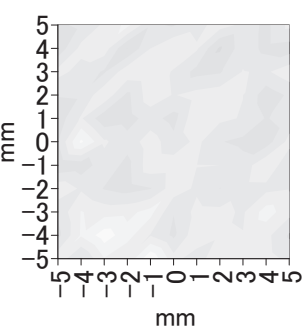

(a) $0 \mathrm{MPa}$

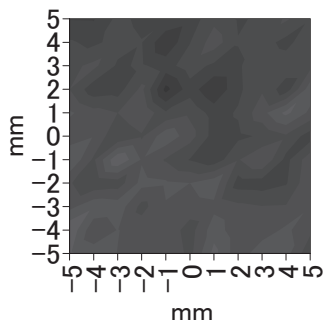

(b) $100 \mathrm{MPa}$

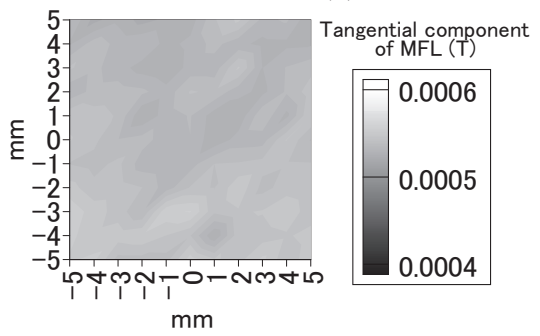

(c) $200 \mathrm{MPa}$

Fig. 6 Distribution of magnetic flux density under tensile stress (SS400).

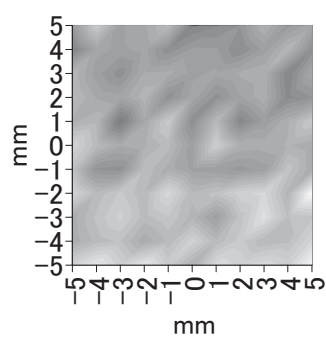

(a) $0 \mathrm{MPa}$

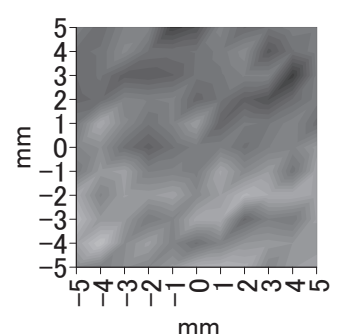

(b) $125 \mathrm{MPa}$

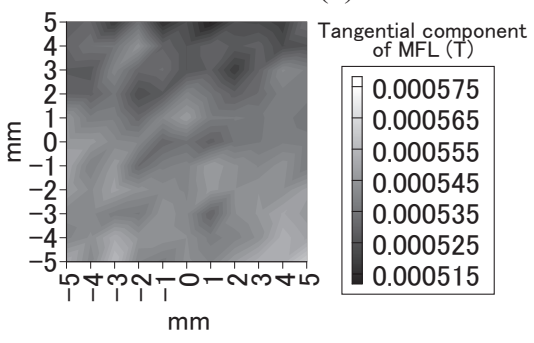

(c) $250 \mathrm{MPa}$
Fig. 7 Distribution of magnetic flux density under tensile stress (SUS304). 
鋼は引張応力の増加とともに残留磁束密度と透磁率が ともに減少傾向を示すことを別途実験により確認して いる $[8]$ 。透磁率の減少は漏洩磁束の増加要因ともなる ため,この二つの要因が重㸚合わさった効果が表れた と考えることもできる。あるいは，鉄系材料では，磁 場や応力の増大とともに磁気弾性結合効果の符号が変 わる（ビラリー反転）効果が知られており，この影響 の可能性もある。いずれにしても，このような傾向の メカニズムを解明することは重要な課題である。

一方，Fig.9(b)を見ると，SUS304 鋼においては測定 值自体は引張応力の増加とともにやや減少する傾向が あるが，Fig.9(c)のように，消磁基準補正值では逆に引 張応力の増加とともに漏洩磁束密度は増加する傾向が 見て取れる。ここで, 各測定值の絶対值を見ると, 一

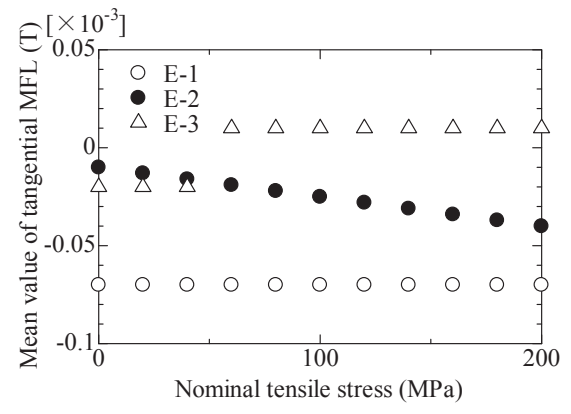

(a) After demagnetization

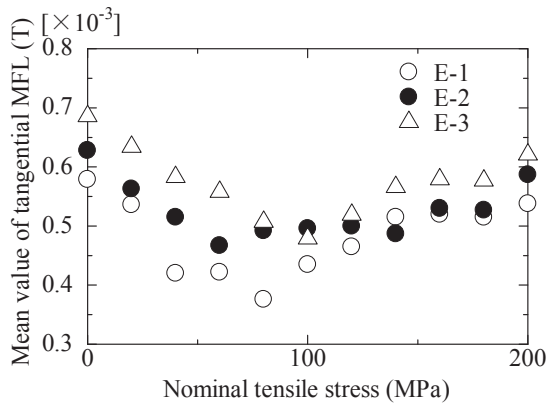

(b) Non-adjusted

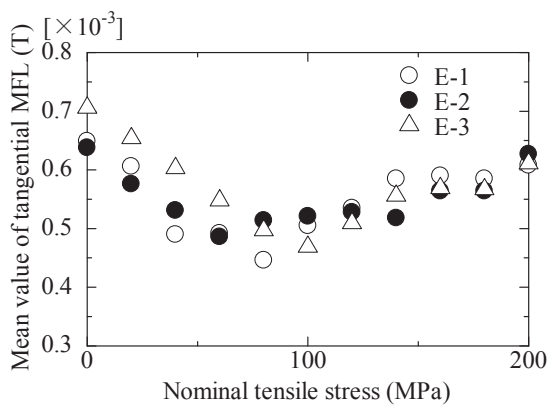

(c) Adjusted (demagnetization base)

Fig. 8 Mean value of MFL density (SS400).
般的な SUS304 鋼の磁性から考えると，ともに非常に 大きな值となっている。また, Fig.9(a)に示した消磁操 作を行った後の漏洩磁束密度值は負值で, かつ引張応 力の増加と共にその絶対值はほぼ線形に増加している。 まず，大きな測定値を示した理由は，試験片加工時の 加工誘起マルテンサイトの生成などによると考えられ る。また, 消磁操作後においても大きな漏洩磁束密度 を示寸理由のひとつは，試験片の消磁が十分に行えな かったことが考えられる。SUS304 鋼試験片の全体的 な透磁率は SS400 鋼などと比べて非常に小さいため, 消磁時に試験片と電磁石とで十分な磁気回路を形成で きず，試験片内で不均一な磁場分布が発生したことが 考えられる。また, 表面近傍の薄い磁性層がシートマ グネットのように複雑な自発磁化分布を生じ，そのた めに通常の消磁操作では十分な消磁が行えなかった可

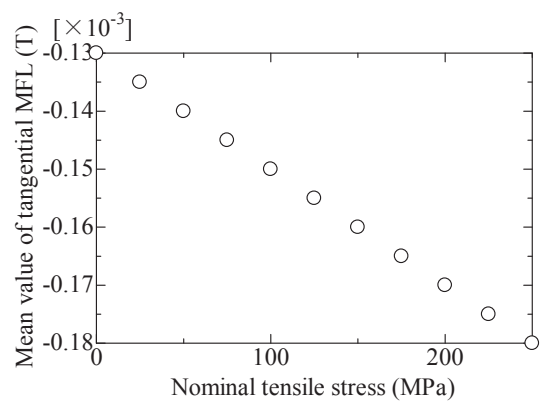

(a) After demagnetization

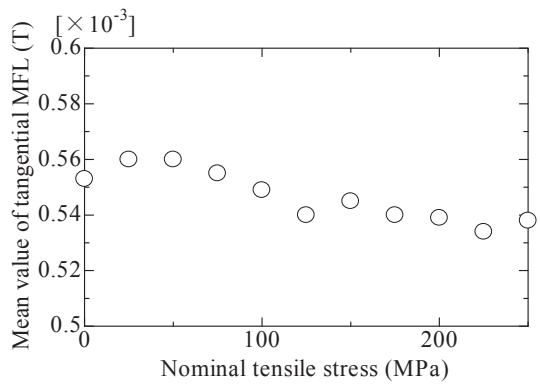

(b) Non-adjusted

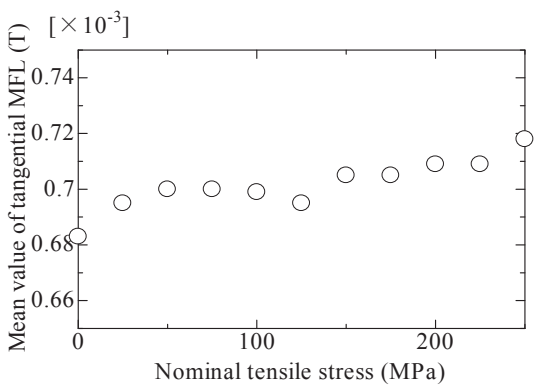

(c) Adjusted (demagnetization base)

Fig. 9 Mean value of MFL density (SUS304). 
能性もある。さらに, 応力に対して線形に変化してい る点については，マルテンサイト相における磁気弾性 結合効果の影響ではないかと考えられる。このような 特殊な磁気的特性の影響の有無と程度を明らかにする には，熱処理などによる表面の加工誘起マルテンサイ 卜相の除去を行った試験片を使用することが望ましい。 このように, SUS304 鋼のようなオーステナイト系ス テンレス鋼について, 漏洩磁束測定によって応力や塑 性変形を評価する場合には, SS400 鋼と異なり独自の 問題，課題が存在する。

\section{2 塑性域}

Fig. 10 および Fig. 11 にはそれぞれ, P-1〜P-4 試験片

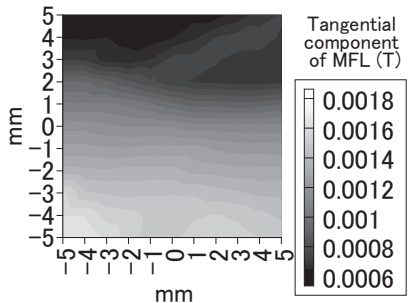

(a) P-1(max strain $1.25 \%$ )

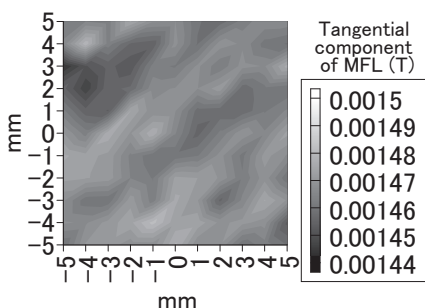

(c) P-3(max strain $3.75 \%$ ) (b) P-2(max strain $2.50 \%)$

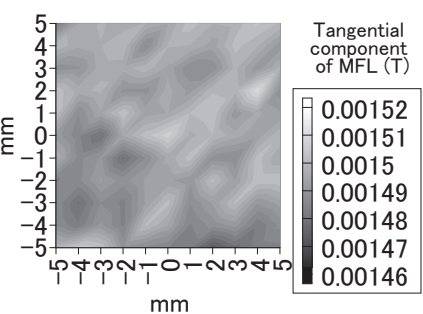

(d) P-4(max strain 5.00\%)

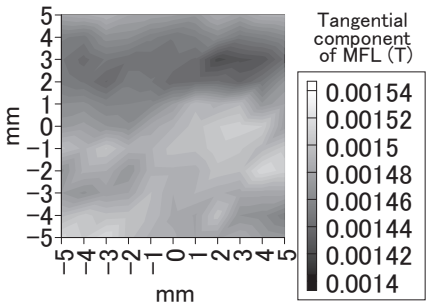

Fig. 10 Mean value of MFL density (SS400).

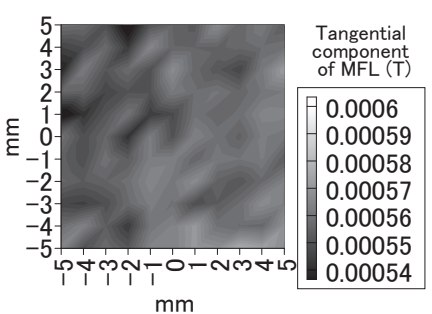

(a) SP-1(max strain $1.00 \%$ )

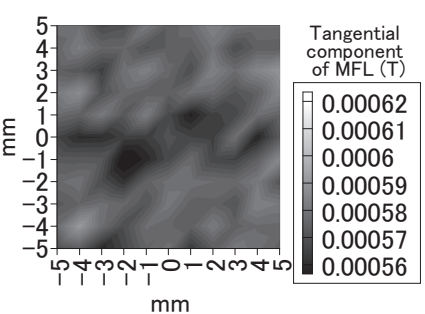

(b) SP-2(max strain $2.00 \%)$

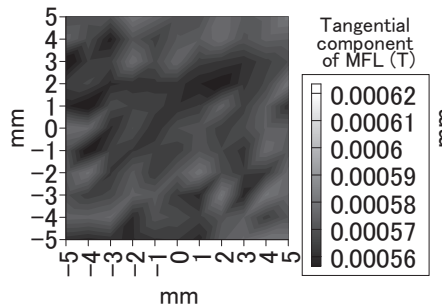

(c) SP-3(max strain $3.00 \%$ )

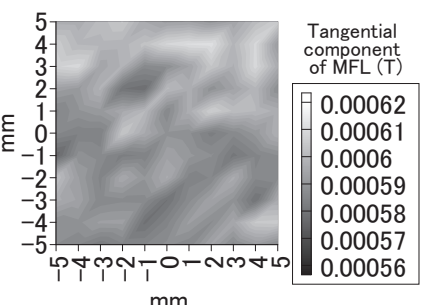

(d) SP-4(max strain $4.00 \%$ )
Fig. 11 Mean value of MFL density (SUS304).
およびSP-1〜SP4 の測定結果を例示した。また，弾性 域の場合と同様, Fig. 12 と Fig. 13 にSS400鋼と SUS304 鋼の各残留ひずみを有する試験片の漏洩磁束密度の測 定領域内の平均值を示した。Fig. 12 より，SS400 鋼に おいては特定の試験片 (図中黒丸および黒三角で表記) を除くと, 漏洩磁束密度の平均值は残留ひず夕によら ずほぼ一定となっていることがわかる。また，その值 は弾性域に比べて非常に大きい。P-1 試験片について は局所的な塑性変形による影響が大きかったと考えら れる。目視によってすべり線が測定部下部（Fig. 10(a) の縦軸-3mm〜 $5 \mathrm{~mm}$ ) に集中しているのも確認している。

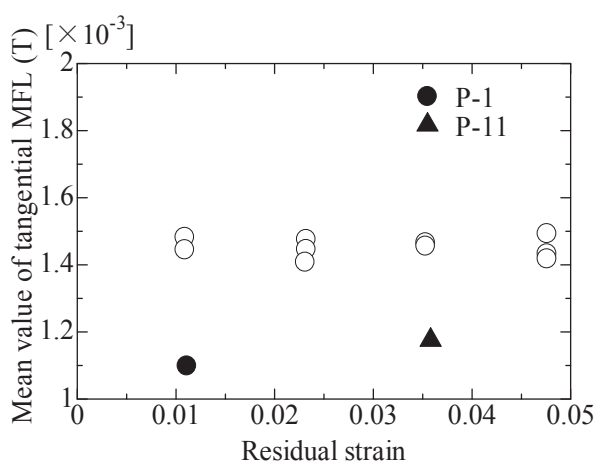

Fig. 12 Mean value of MFL density of P specimen (SS400).

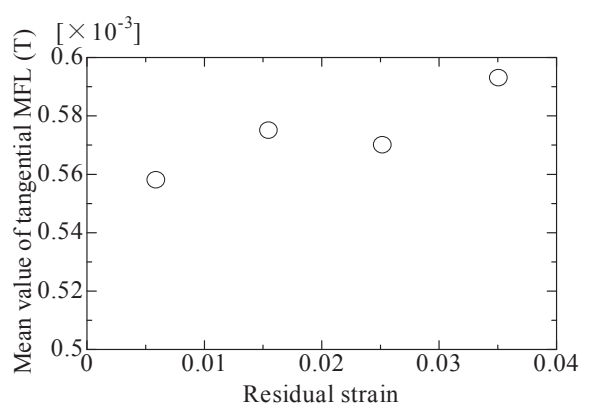

(a) Non-adjusted

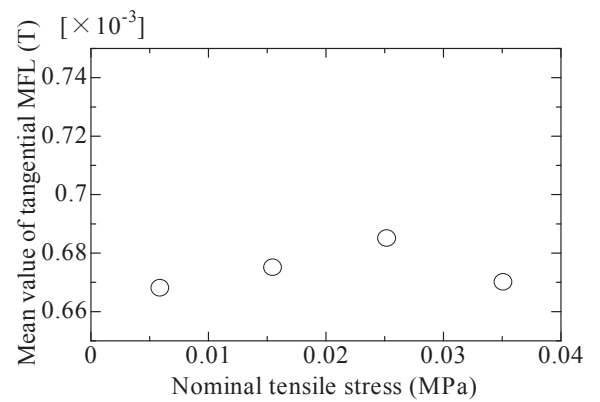

(b) Adjusted (demagnetization base)

Fig. 13 Mean value of MFL density of SP specimen (SUS304). 
これは，最大引張ひずみ $1.25 \%$ 付近ではまだ降伏途中 であり, 全体が均一に塑性変形していないためである。 また, P-11 試験片については, 試験片作成時の引張試 験データが他の試験片と異なる傾向を示していること を確認しており, 引張試験の不良もしくは異なる塑性 変形分布を生じている可能性が高い。

一方, Fig. 13(a)からわかるように, SUS304 鋼におい ては残留ひずみの増加とともに漏洩磁束密度は増加す る傾向が見られたが，Fig. 13(b)に示すように消磁状態 を基準とした補正を施すと，SS400 鋼と同様に漏洩磁 束密度の平均值は残留ひずみによらずほぼ一定となっ ている。ただし, 両者ともに弾性域と比較すると大き

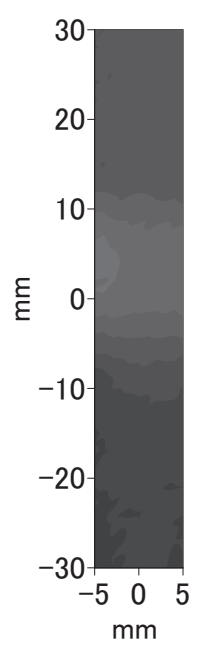

(a) D-1

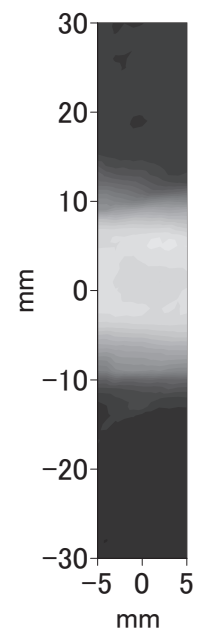

(b) D-2

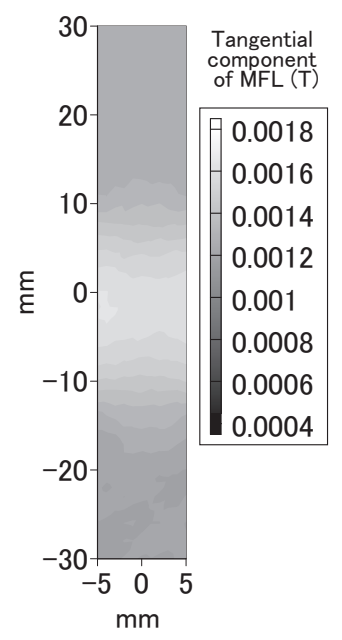

(c) D-3
Fig. 14 MFL distribution of D specimen (SS400).

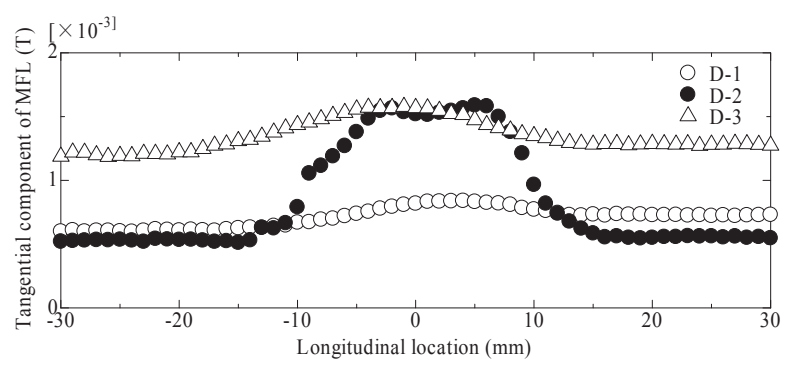

Fig. 15 MFL distribution on midline of D specimen.

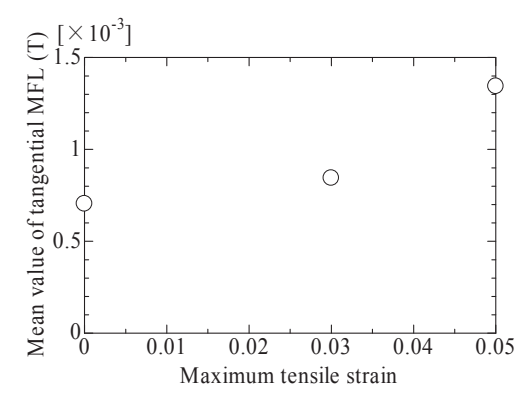

Fig. 16 Mean value of MFL density.
な值を示している。これは，塑性変形によるマルテン サイト相の生成に対応していると考えられ，両者の值 の違いは前述のように今回行った消磁操作で消磁しき れなかった残留磁化の増加に対応すると考えられる。

\section{3 残留ひずみ・残留応力分布}

Fig. 14 に, SS400 鋼の応力集中型試験片（D 試験片） に塑性域の応力を負荷・除荷した後に測定した漏洩磁 束密度分布を示した。Fig. 14(a)は無荷重状態（D-1 試 験片), Fig. 14(b)は最大引張ひずみ 3\% (D-2 試験片), Fig. 14(c)は最大引張ひずみ 5\%（D-3 試験片）の場合の 測定結果である。また，Fig. 15 には各試験片の中央線 に沿った漏洩磁束密度分布を, Fig. 16 には測定領域内 の漏洩磁束密度の平均值を示した。Fig. 14 および Fig. 15 からわかるように, 中央部に塑性変形を有する D-2, D-3 試験片ではいずれも漏洩磁束密度が中央で最大と なっており,その值は最大ひずみによらずほぼ等しい。 D-2 試験片では，中央部以外の周囲で無荷重の試験片 （D-1 試験片）よりも低い漏洩磁束密度となっている。 これは，中央部以外では塑性変形が生じておらず，か つ弾性域の測定結果より, 引張の残留応力による効果 と考えられる。また，D-3 試験片では，広い範囲で漏

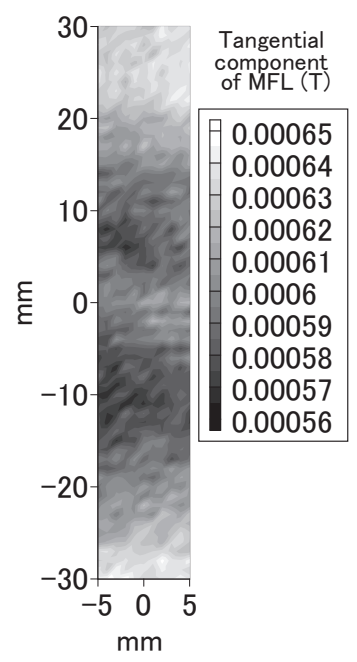

Fig. 17 MFL distribution of SD specimen (SUS304).

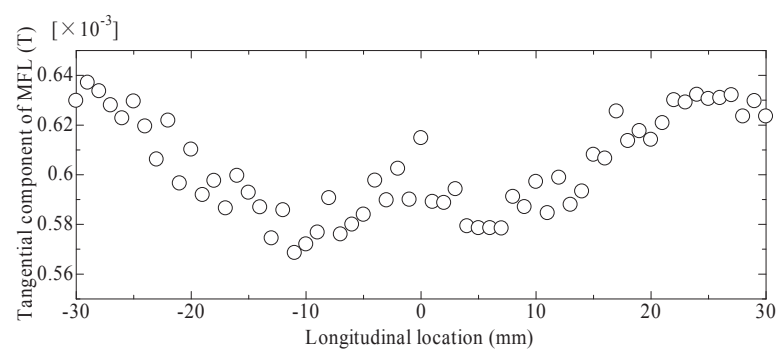

Fig. 18 MFL distribution on midline of SD specimen. 
洩磁束密度が高くなっている。試験片作成時の引張試 験結果より, D-3 試験片では降伏現象が段階的に複数 回起こっており, 測定領域内において全体的に塑性変 形していると考えられる。一方, 無荷重の試験片 D-1 も中央部で漏洩磁束密度が若干増加しているが, 試験 片のR部において試験片を通過する磁束が増大してい る効果であると考えられる。これらの結果を踏まえ Fig. 16 をみると, 中央周辺部の引張残留応力による漏洩磁 束密度の若干の低下にもかかわらず，中央部を中心と した塑性変形や圧縮残留応力分布による漏洩磁束密度 の増大が, 測定領域内での平均值の増大をもたらして いると説明できる。つまり, 測定領域内での磁束密度 の平均值を取ることによって, 残留応力分布の影響は 軽減され, 測定領域内に占める塑性変形部の割合を推 測できると考えられる。このことから, 測定領域内で の平均的な塑性変形の程度についても推測可能ではな いかと考えられる。以上のように, SS400 鋼において は, 漏洩磁束測定によって塑性変形や残留応力の分布, およびその程度を推定することが可能であることが示 された。

他方, Fig. 17 に, SUS304 鋼の応力集中型試験片 (SD 試験片）に塑性域の応力を負荷・除荷した後に測定し た漏洩磁束密度分布を示した。また, Fig. 18 は試験片 中央線に沿った漏洩磁束密度分布である。これらの結 果から, 漏洩磁束密度は測定領域両端で最も大きな值 を示しており, 試験片中央に向かうにつれて減少, 中 央の塑性変形部で小さなピークを示していることがわ かる。測定領域両端で大きな磁束密度を示しているの は, 前節で述べたように, 着磁時に試験片と電磁石と で十分な磁気回路を形成できないために, 試験片中で 不均一な磁場がかかり, 磁極近傍がより強く磁化され たためであると考えられる。一方で, 測定值の絶対值 をみると, 試験片中央部では $0.6(\mathrm{~T})$ 程度で, その周 辺部では $0.56(\mathrm{~T})$ 程度の值となっている。これは, 前節までの測定結果を踏まえると, 中央部では塑性変 形時の平均的な值であり, 周辺部では弾性域の平均的 な值をとっていることがわかる。このように SUS304 鋼では, 試験片および測定環境の影響が大きいものの, 塑性変形の有無およびその分布を確認することが可能 であることが示された。

\section{4 結言}

本研究では, SS400 鋼とSUS304 鋼を対象として, 材料表面近傍の漏洩磁束を測定することで, 塑性変形
や応力の分布を評価することを試みた。

SS400 鋼については,

1) 弾性域の引張応力の増大とともに漏洩磁束密度 はいったん減少した後にやや増加する。このメ カニズムの詳細は明らかではないが，ビラリー 反転効果の影響などが考えられる。

2) 残留ひずみの程度によらず漏洩磁束密度はほぼ 一定の值となった。ただし, その值は弾性域の ものと比較すると非常に大きい。

3) 測定される漏洩磁束密度分布から塑性変形部お よび残留応力の分布を推定することが可能であ ることを確認した。また, その漏洩磁束密度の 平均值から, 測定領域においてどの程度塑性変 形が進行しているかを推測できる可能性を確認 した。

続いて, SUS304 鋼については,

1) 弾性域の引張応力の増大とともに漏洩磁束密度 は減少する傾向がある。しかし, 消磁状態を基 準とした補正を施すと, 逆に応力の増加ととも に漏洩磁束密度は増加する傾向があることがわ かった。

2) 残留ひずみが増加すると漏洩磁束密度も増加す る傾向が見られた。しかし, 消磁状態を基準と した補正を施すと, 残留ひずみの程度によらず 漏洩磁束密度はほぼ一定となった。

3）上述のように，消磁状態を基準とした補正を施 した場合, 元の測定值と傾向が異なるのは, 試 験片と電磁石とで十分な磁気回路を形成するこ とができず，不均一な磁場下で適切な消磁およ び着磁が出来なかったためであると考えられる。 SUS304 鋼にはこのような材料特有の問題が存 在し, 試験条件についての十分な検討が必要で あることがわかった。

4) 測定される漏洩磁束密度分布から, 塑性変形部 の分布を推定することが可能であることを確認 した。

といった知見を得た。今後は，材料に適した着磁方法 や測定条件について検討するとともに基礎デー夕を蓄 積し, 続いて実際に過負荷による大変形を生じた部材 の残留応力や残留ひずみの分布，ならびに疲労損傷の 評価など，実機での評価を通して本手法の有効性の検 証をおこなっていきたい。

(2012 年 10 月 1 日受付, 2013 年 2 月 27 日再受付) 


\section{参考文献}

[1] R. M. Bozorth, Ferromagnetism, , Van Nostrand, 1951.

[2] 山崎ら, 磁歪特性を利用した軟鋼の非破壊残留応力測定, 日本機械学会論文集 A，Vol. 63，pp. 1489-1494， 1997.

[3] 関口ら, 外部磁束密度計測による強磁性鋼の応力-透磁率 関係の定量評価, 日本機械学会論文集 A, Vol. 60, pp.1617-1623, 1994.

[4] 山崎ら, 引張荷重負荷時の磁化特性に着目した構造材の 劣化評価, 日本応用磁気学会誌, Vol. 23, No. 4-2, pp. 9-17, 2001.

[5] 高橋, 磁気と塑性一非破壊検査一の応用, 日本 AEM 学 会誌, Vol. 9, No. 2, pp. 9-17, 2001.

[6] 中曽根ら, マルテンサイト変態を利用した電磁的材料劣 化評価, 日本 AEM 学会誌, Vol. 9, No. 2, pp. 123-130, 2001.

[7] 槌田ら, 磁気センサによる SUS304 系鋼・SUS316 系鋼の 歪および曲げ疲労評価, 非破壊検査, Vol. 57, No. 9, pp. 433-436, 2008.

[8] 渡邊, 低炭素鋼の磁化特性を利用した応力・塑性変形・ 疲労の評価, 京都大学大学院エネルギー科学研究科修士 学位論文, 2013. 